\title{
Effect of grain refinement on the mechanical and shape memory properties of Cu-Al-Mn base alloys
}

\author{
Y. Sutou, T. Omori, T. Okamoto, R. Kainuma and K. Ishida \\ Department of Materials Science, Graduate School of Engineering, Tohoku University, Aramaki \\ Aoba-yama 02, Sendai 980-8579, Japan
}

\begin{abstract}
The effect of grain refinement on the mechanical and shape memory (SM) properties of the $\beta$ phase $\mathrm{Cu}-$ Al-Mn alloys with $\mathrm{L} 2{ }_{1}$ structure were investigated by optical microscopy, scanning electron microscopy, differential scanning calorimetry and tensile-testing. Additions of $\mathrm{V}$ or $\mathrm{Cr}$ to the $\mathrm{Cu}-\mathrm{Al}-\mathrm{Mn}$ ternary alloy in amounts over 0.5 at. $\% \mathrm{~V}$ or lat. $\% \mathrm{Cr}$ were effective in refining the $\beta$ phase grain sizes to less than $200 \mu \mathrm{m}$. The $\mathrm{M}_{\mathrm{s}}$ temperature decreased with increasing $\mathrm{V}$ or $\mathrm{Cr}$ content, obeying the Hall-Petch type relation with the $\beta$-grain size. The mechanical properties were improved, but the SM and pseudoelastic properties were not improved by grain refinement.
\end{abstract}

\section{Introduction}

Cu-based shape memory (SM) alloys of the $\mathrm{Cu}-\mathrm{Zn}-$ and $\mathrm{Cu}-\mathrm{Al}$-based systems are commercially attractive for the manufacture of SM devices because of their low cost. However, these highly ordered, large-grained polycrystalline $\mathrm{Cu}$ based alloys are not always amenable to cold working and also suffer from very low fatigue strength. Consequently, many attempts have been made to improve the ductility by reducing the $\beta$ grain size, especially by additions of less-soluble alloying elements $[1,2]$. In the case of the $\mathrm{Cu}-\mathrm{Al}$ $\mathrm{Ni}$ and $\mathrm{Cu}-\mathrm{Zn}-\mathrm{Al} \mathrm{SM}$ alloys, it has been reported that the addition of alloying elements, such as $\mathrm{Ti}$, $\mathrm{Cr}, \mathrm{Zr}, \mathrm{V}, \mathrm{Pb}$ or $\mathrm{B}$, results in some $\beta$-grain size refinement and improvement in ductility.

Recently, the present authors have reported that additions of about $10 \mathrm{at} . \% \mathrm{Mn}$ to the $\mathrm{Cu}-\mathrm{Al}$ system widen the $\beta$ phase field [3] and also that the group of $\mathrm{Cu}-\mathrm{Al}-\mathrm{Mn}$ alloys with $\mathrm{Al}$ contents lower than 18 at. \% exhibits better cold-workability without the associated loss in the SM properties. The reason for the increased ductility in these alloys is attributed to the decrease in the degree of order in the parent $\mathrm{L} 2{ }_{1}$ phase $[4,5]$.

In this paper, we report the results of investigations carried out to further improve the ductility of $\mathrm{Cu}-\mathrm{Al}-\mathrm{Mn}$ alloys through grain refinement of the $\mathrm{Cu}-\mathrm{Al}-\mathrm{Mn} \beta$ phase by the addition of very low solubility elements $\mathrm{V}$ or $\mathrm{Cr}$. The effect of these additions on the $M_{s}$ temperature,

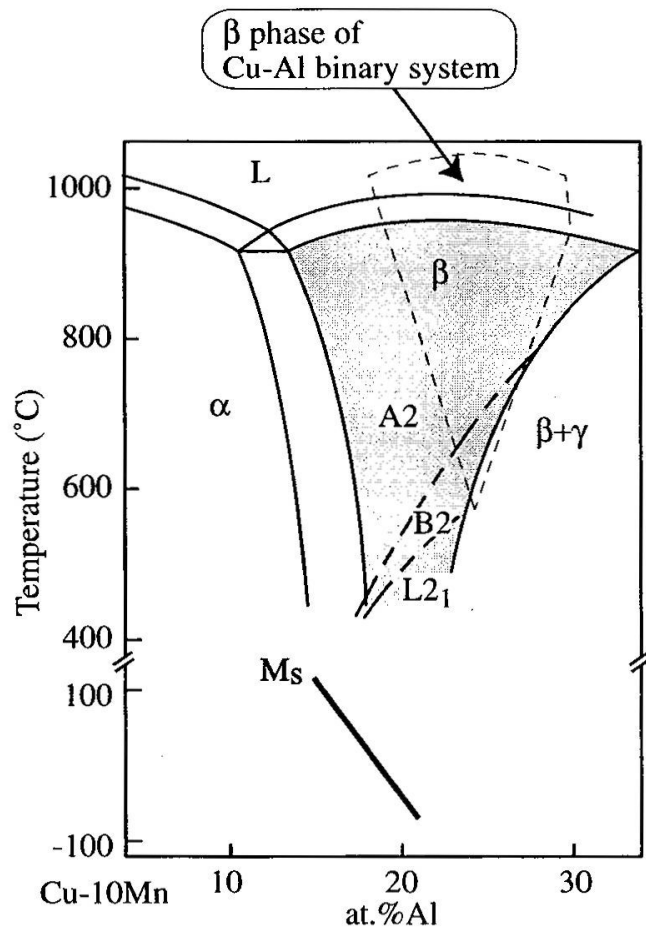

Figure 1 Vertical section diagram of the $\mathrm{Cu}-\mathrm{Al}-10 \mathrm{at} . \% \mathrm{Mn}$ system comparing the stability of $\beta$ phase region in the $\mathrm{Cu}-\mathrm{Al}$ binary system. 
ductility, mechanical and SM properties of the $\mathrm{Cu}-\mathrm{Al}-\mathrm{Mn}$ alloys are reported.

\section{Experimental Procedures}

Single-phase $\beta$ alloys of the $\mathrm{Cu}-\mathrm{Al}-\mathrm{Mn}-\mathrm{V}$ or $\mathrm{Cu}-\mathrm{Al}-\mathrm{Mn}-\mathrm{Cr}$ quaternary systems were prepared by a special induction melting technique as described in our previous paper [6], keeping the $\mathrm{Al} / \mathrm{Mn}$ composition ratio constant. Alloy designations and their nominal composition are shown in Table 1. Sheet specimens of about $2.0 \mathrm{~mm}$ thickness were prepared by hot-rolling the cast alloy at $800^{\circ} \mathrm{C}$. All specimens were solutiontreated at $900^{\circ} \mathrm{C}$ for 15 minutes and quenched into ice water. Some of them were aged at $200^{\circ} \mathrm{C}$ for 15 minutes to stabilize the $M_{s}$ temperature. $\beta$ grain size was determined by optical microscopic observations. The compositions of the $\beta$ phase and

Tabel 1 Nominal composition of alloys.

\begin{tabular}{|c|c|c|c|c|c|c|}
\hline \multirow{2}{*}{$\begin{array}{c}\text { Alloy } \\
\text { Designation }\end{array}$} & \multicolumn{2}{|c|}{$\begin{array}{c}\text { Composition of } \\
\text { Mother Alloy } \\
\text { /at.\% }\end{array}$} & \multicolumn{2}{|c|}{\begin{tabular}{c}
\multicolumn{2}{|c|}{ Alloying } \\
Element/ at.\%
\end{tabular}} \\
\cline { 2 - 7 } & $\mathrm{Cu}$ & $\mathrm{Al}$ & $\mathrm{Mn}$ & - & $\mathrm{V}$ & $\mathrm{Cr}$ \\
\hline $0 \mathrm{~V}$ & bal. & 16 & 10 & & - & - \\
$0.1 \mathrm{~V}$ & & & & & 0.1 & - \\
$0.5 \mathrm{~V}$ & & & & & 0.5 & - \\
$1 \mathrm{~V}$ & & & & & 1 & - \\
\hline $0 \mathrm{Cr}$ & bal. & 17 & 10 & & - & - \\
$0.5 \mathrm{Cr}$ & & & & & - & 0.5 \\
$1 \mathrm{Cr}$ & & & & & - & 1 \\
$2 \mathrm{Cr}$ & & & & & - & 2 \\
\hline
\end{tabular}

the precipitates in each specimen were analyzed using a combination of scanning electron microscopy and energy dispersive spectroscopy (SEM-EDS). The martensitic transformation temperatures were determined by differential scanning calorimetry (DSC) at a heating and cooling rate of $10^{\circ} \mathrm{C} /$ minutes. The cold workability was evaluated by measuring the minimum thickness attained before a crack appeared during cold rolling at room temperature. The mechanical and pseudoelastic (PE) properties were examined by tensile testing techniques on $25 \times 4 \times 2 \mathrm{~mm}$ tensile specimens. Fractographic study to observe the tensile fracture surface was carried out by scanning electron microscopy (SEM).

\section{Result and Discussion}

\section{3-I. The effect of $V$ or $C r$ addition on the $\beta$-grain size}

The microstructures of all the $\mathrm{V}$ and $\mathrm{Cr}$ containing alloys after hot-rolling at $800^{\circ} \mathrm{C}$ followed by recrystallization at $900^{\circ} \mathrm{C}$ for 15 minutes are shown in Figure 2. The mean values of the $\beta$-grain sizes measured from each specimen microstructure shown in Figure 2 are listed in Table 2. It is seen that the

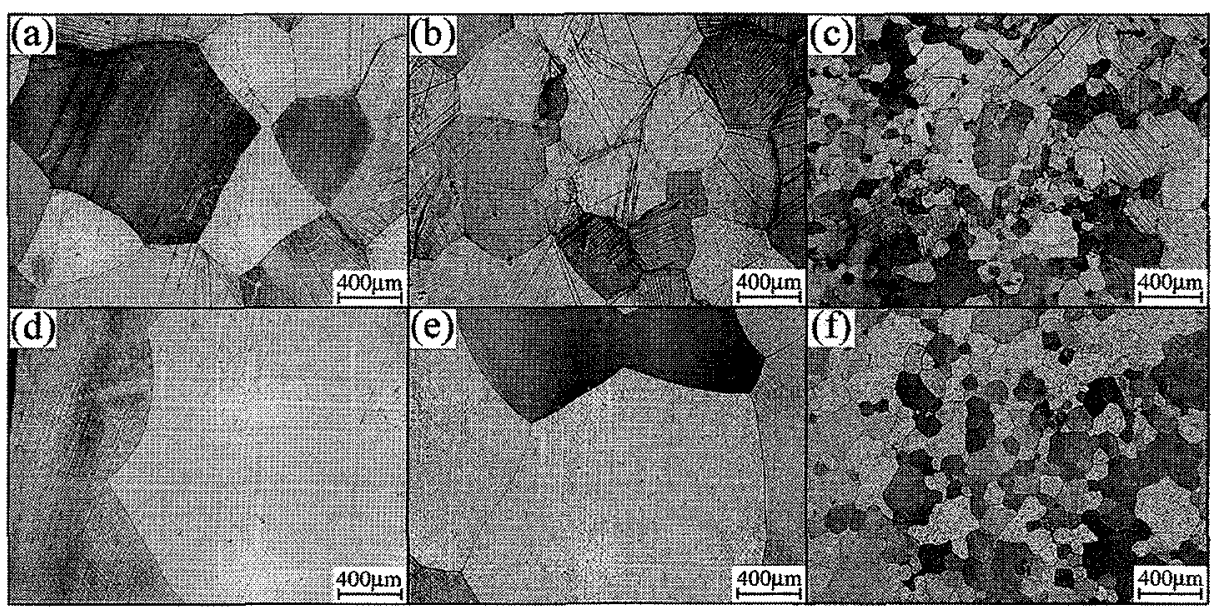

Figure 2 Optical microstructures of Cu-Al-Mn-X alloys after solution treatment. (a) Cu-16at.\%Al-10at.\%Mn (b) -0.1 at.\%V (c) -0.5 at. \%V, (d) Cu-17at.\%Al-10at.\%Mn, (e) -0.5 at.\%Cr and (f) -2.0 at. \% Cr. 
Table 2 Phase constitution, mean grain size, martensitic transformation temperatures, mechanical and PE properties of as-aged $\mathrm{Cu}-\mathrm{Al}-\mathrm{Mn}-\mathrm{V}$ and-Cr alloys.

\begin{tabular}{|c|c|c|c|c|c|c|c|c|c|c|c|c|}
\hline \multirow{2}{*}{$\begin{array}{c}\text { Alloy } \\
\text { Designation }\end{array}$} & \multirow{2}{*}{$\begin{array}{c}\text { Phase } \\
\text { Constitution } \\
\mathrm{S}: \beta \text { sihgle } \\
\mathrm{P}: \beta+\text { prec. } \\
\end{array}$} & \multirow{2}{*}{$\begin{array}{c}\text { Mean } \\
\text { Grain } \\
\text { Diameter } \\
(\mu \mathrm{m})\end{array}$} & \multicolumn{4}{|c|}{$\begin{array}{c}\text { Martensitic } \\
\text { Transformation } \\
\text { Temperatures }\left({ }^{\circ} \mathrm{C}\right)\end{array}$} & \multicolumn{3}{|c|}{$\begin{array}{c}\text { Mechanical Properties } \\
\text { at R.T. }\end{array}$} & \multicolumn{2}{|c|}{$\begin{array}{l}\text { PE properties } \\
\text { at } \mathrm{A}_{\mathrm{f}}+30^{\circ} \mathrm{C}\end{array}$} & \multirow{2}{*}{$\begin{array}{c}\text { PE recovery } \\
(\%)\end{array}$} \\
\hline & & & $\frac{1 \text { en }}{M_{s}}$ & $\mathrm{M}_{\mathrm{f}}$ & aures & $\frac{(C)}{A_{f}}$ & $\begin{array}{c}\text { elongation } \\
(\%)\end{array}$ & $\underset{(\mathrm{MPa})}{\sigma_{\mathbf{y}}}$ & $\begin{array}{c}\delta \sigma_{M} / \delta \varepsilon \\
(\mathrm{GPa})\end{array}$ & $\begin{array}{c}\sigma_{\mathrm{c}} \\
(\mathrm{MPa})\end{array}$ & $\begin{array}{c}\delta \sigma_{\mathrm{PE}} / \delta \varepsilon \\
(\mathrm{GPa})\end{array}$ & \\
\hline ov & $\mathbf{S}$ & 750 & 76 & 59 & 81 & 97 & 12.4 & 79.3 & 1.23 & 164.6 & 1.21 & 65 \\
\hline $0.1 \mathrm{~V}$ & $\mathbf{P}$ & 410 & 72 & 58 & 78 & 92 & 14.2 & 122.4 & 2.22 & - & - & - \\
\hline $0.5 \mathrm{~V}$ & $\mathbf{P}$ & 230 & 65 & 42 & 69 & 87 & 18.2 & 137.9 & 2.96 & 351.5 & 3.04 & 52 \\
\hline $1 \mathrm{~V}$ & $\mathbf{P}$ & 230 & 65 & 46 & 72 & 88 & - & - & - & - & - & - \\
\hline $0 \mathrm{Cr}$ & $\mathbf{S}$ & 1014 & 57 & 36 & 63 & 76 & 12.9 & 148.3 & 2.93 & 157.5 & 2.07 & 75 \\
\hline $0.5 \mathrm{Cr}$ & $\mathbf{S}$ & 1241 & 55 & 34 & 62 & 77 & 6.8 & 156.9 & 2.86 & 182.9 & 1.94 & 73 \\
\hline $1 \mathrm{Cr}$ & $\mathbf{P}$ & 196 & 40 & 2 & 48 & 69 & 7.6 & 177.3 & 4.71 & 214.0 & 2.23 & 68 \\
\hline $2 \mathrm{Cr}$ & $\mathbf{P}$ & 188 & 39 & -12 & 53 & 70 & 7.9 & 191.4 & 4.58 & 251.2 & 3.05 & 67 \\
\hline
\end{tabular}

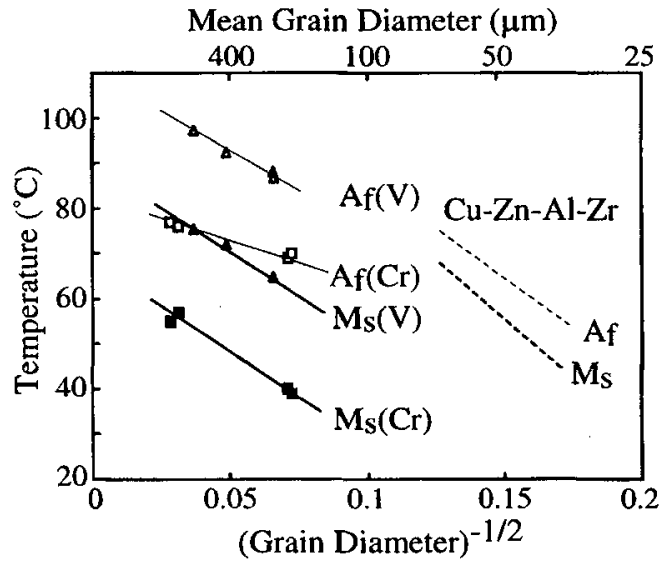

Figure 3 Changes of $M_{s}, M_{f}, A_{s}$ and $A_{f}$ temperatures with (grain diameter) $-1 / 2$.

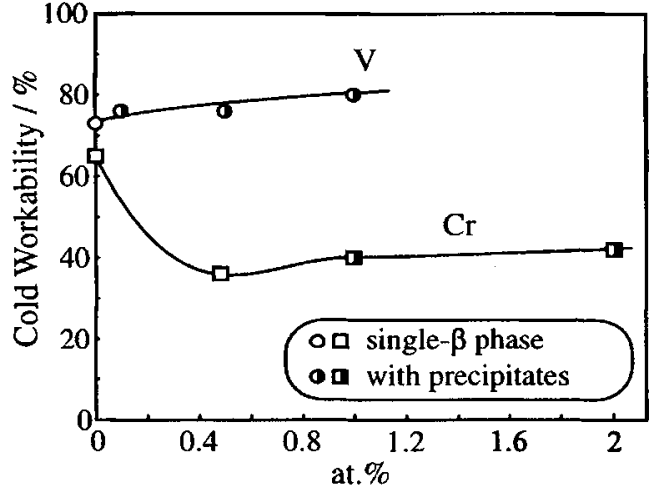

Figure 4 Effect of $\mathrm{V}$ and $\mathrm{Cr}$ on the cold workability.

mean $\beta$-grain size is reduced when the $\mathrm{V}$ content exceeds 0.1 at. $\% \mathrm{~V}$ or the $\mathrm{Cr}$ content exceeds $1 \mathrm{at} . \% \mathrm{Cr}$. It was confirmed by SEM observation and EDS analysis that such grain refinement was due to the pinning effect of the dispersed $\mathrm{V}$ or $\mathrm{Cr}$ particles segregated at the grain boundary.

\section{3-2. Martensitic Transformation Temperatures}

Martensitic transformation temperatures in all the quenched and aged specimens of $\mathrm{Cu}-\mathrm{Al}-\mathrm{Mn}$ alloys determined by DSC analysis are given in Table 2. The martensitic transformation temperatures are decreased by the additions of $\mathrm{V}$ and $\mathrm{Cr}$. It has been reported that the martensitic transformation temperatures are a function of the grain size in the case of some ferrous systems $[7,8]$ and some Cu-based alloys $[9,10]$. Figure 3 shows the variation of $M_{s}$ and $A_{f}$ temperatures with $\beta$ grain size in the $\mathrm{Cu}-\mathrm{Al}$ $\mathrm{Mn}-\mathrm{V}$ or - $\mathrm{Cr}$ alloys, in comparison with similar data from a $\mathrm{Cu}-\mathrm{Zn}-\mathrm{Al}-\mathrm{Zr}$ alloy [10]. There exists a HallPetch type relation between the martensitic transformation temperatures and the $\beta$-grain size in both the $V$ and $\mathrm{Cr}$ containing $\mathrm{Cu}-\mathrm{Al}-\mathrm{Mn}$ alloys, and the change in the martensitic transformation temperatures as a function of grain size is almost the same in all the alloys including the $\mathrm{Cu}-\mathrm{Zn}$-based one. 


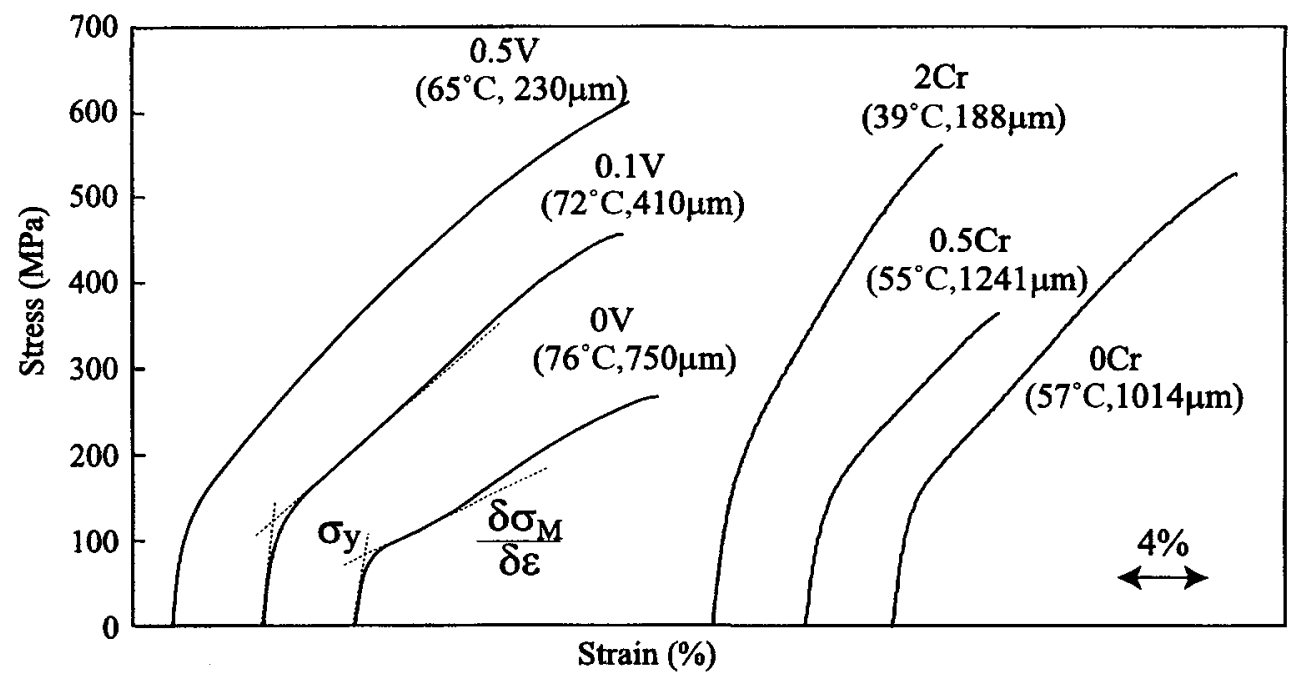

Figure 5 Stress-strain curve obtained by tensile testing at room temperature. The parenthesis indicates the $M_{S}$ temperature and the mean grain size of each alloy.

\section{3-3. Mechanical Properties}

Effects of $\mathrm{V}$ and $\mathrm{Cr}$ additions on the cold-workability of the as-annealed alloys are plotted in Figure 4. It is clear that while the room temperature cold workability of the $\mathrm{Cu}-\mathrm{Al}-\mathrm{Mn}$ alloys increases slightly with $\mathrm{V}$ additions, $\mathrm{Cr}$ additions of as little as 0.5 at.\% drastically decrease their cold workability which is barely improved by further $\mathrm{Cr}$ addition. Even though these results suggest that the improvement in the cold workability on adding $\mathrm{V}$ to $\mathrm{Cu}-\mathrm{Al}-\mathrm{Mn}$ alloy is mainly due to grain size refinement, as is the case in other $\mathrm{Cu}$-based SM alloys, it is not readily obvious why the single-phase $\mathrm{Cu}-\mathrm{Al}-\mathrm{Mn} \beta$ alloy dissolving 0.5 at. $\% \mathrm{Cr}$ should show such drastic loss of ductility.

Tensile stress-strain curves for some post-quench aged specimens tested in the martensite state at room temperature are shown in Figure 5. It can be seen that the addition of $0.5 \mathrm{at} . \% \mathrm{~V}$ increases the fracture stress to more than $600 \mathrm{MPa}$ and the elongation to over $18 \%$. The addition of 0.5 at. $\% \mathrm{Cr}$ reduces the fracture stress and the elongation, in keeping with the effect of such addition oncold workability. For both the $\mathrm{V}$ and $\mathrm{Cr}$ containing $\mathrm{Cu}-\mathrm{Al}-\mathrm{Mn}$ alloy systems the yield stresses $\sigma_{\mathrm{y}}$ and the work hardening rate defined by the slope $\delta \sigma_{M} / \delta \varepsilon$ after yielding, increase with decreasing $\beta$ phase grain size. It has been proposed that the increase in the yield stress $\sigma_{y}$ at a temperature below $M_{s}$ in fine grained alloys is due to the increase in grain constraint that causes a decrease in the thickness of the martensite plates [11-13]. Sure and Brown [12] and White et al [13] have suggested that the increase in the value of the slope $\delta \sigma_{\mathrm{M}} / \delta \varepsilon$ with decreasing

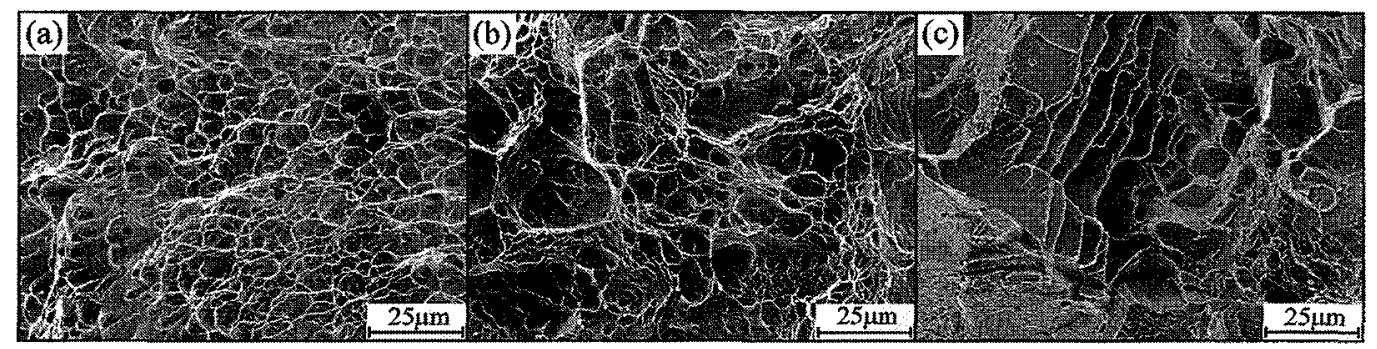

Figure 6 SEM photographs of fracture surfaces of Cu-Al-Mn-X alloys at room temperature. (a), (b) and (c) are the fracture surfaces of $0 \mathrm{Cr}, 0.5 \mathrm{~V}, 2 \mathrm{Cr}$, respectively. 
$\beta$-grain size in the martensite state is due to the restraint imposed on the migration of the twin boundaries and reorientation of the variants by the reduction in grain size. Taken together, they seem to explain why the yield stress and the work hardening rate are higher in the smaller grained martensite phase. All the tensile test data obtained in this study are listed in Table 2.

Figure 6 (a), (b), and (c) are the SEM micrographs from the fracture surfaces of $0 \mathrm{Cr}, 0.5 \mathrm{~V}$ and $2 \mathrm{Cr}$ containing $\mathrm{Cu}-\mathrm{Al}-\mathrm{Mn}$ tensile test specimens respectively. In the case of the $0 \mathrm{Cr}$ and $0.5 \mathrm{~V}$ containing alloys, typical dimple patterns are observed in some areas, the size of the dimples in the $0 \mathrm{Cr}$ alloysbeing slightly smaller than those in the 0.5 Vcontaining alloy. On the other hand, coexisting intergranular and cleavage type fracture surfaces are observed in the $2 \mathrm{Cr}$ containing alloy. Since the $0.5 \mathrm{Cr}$ containing alloy with a large grain size and no precipitate also exhibits a typical intergranular fracture, it can be concluded that the change of the fracture type on adding $\mathrm{Cr}$ is not due to the precipitation of $\mathrm{Cr}$ particles. The reason why the fracture mode changes to the intergranular type on addition of $\mathrm{Cr}$ is not clear at present, but one possibility is that solid solution hardening causes stress concentration near grain boundaries.

These results suggest that addition of $\mathrm{V}$ to the $\mathrm{Cu}-\mathrm{Al}-\mathrm{Mn}$ alloy is an effective method to improve the mechanical properties of the $\mathrm{Cu}-\mathrm{Al}-\mathrm{Mn}$ based alloys, but the addition of $\mathrm{Cr}$ is not

\section{3-4. Pseudo-elasticity}

Figure 7 and 8 show cyclic stress-strain curves for $0 \mathrm{~V}, 0.5 \mathrm{~V}$ and $0 \mathrm{Cr}, 2 \mathrm{Crcontaining}$ alloys respectively, obtained by testing in an Instron machine. The as-quenched and as-aged specimens of all the alloys were examined at the temperature $\mathrm{A}_{\mathrm{f}}+30^{\circ} \mathrm{C}$ where they were expected to show pseudo-elastic (PE) properties. The nature of the stress-strain curves are strongly affected by adding $\mathrm{V}$ and $\mathrm{Cr}$, especially the critical stress $\sigma_{\mathrm{c}}$ for the onset of $\mathrm{PE}$ and the gradient $\delta \sigma_{\mathrm{PE}} / \delta \varepsilon$ of the PE curve in the plateau region. Both quantities
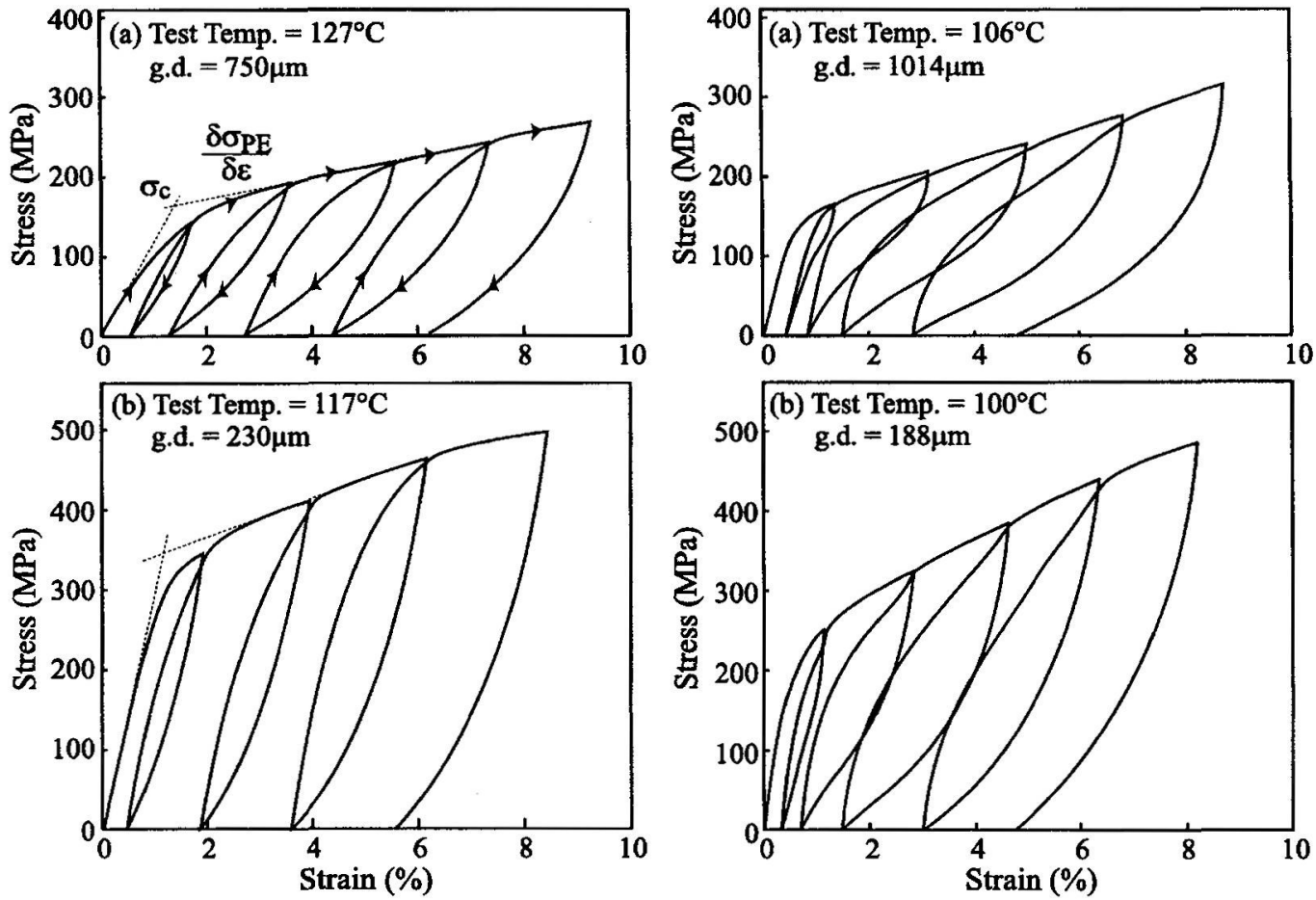

Fig.7 Cyclic stress strain curve of (a) $0 \mathrm{~V}$ and (b) $0.5 \mathrm{~V}$ alloy tested at $\mathrm{A}_{\mathrm{f}}+30^{\circ} \mathrm{C}$.

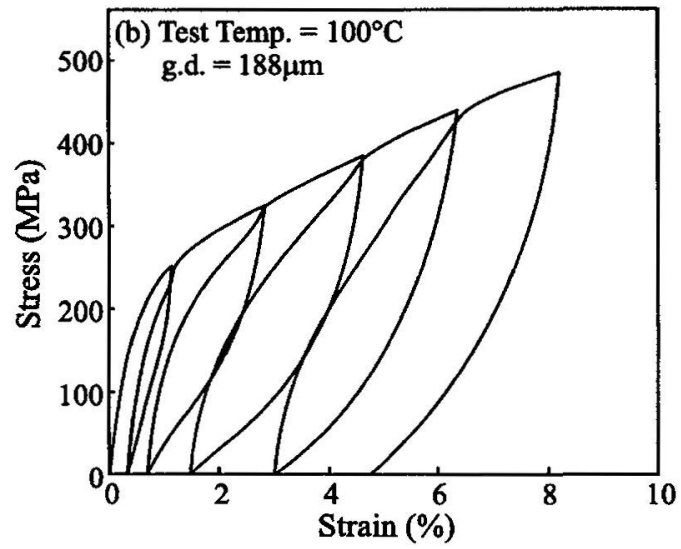

Fig.8 Cyclic stress strain curve of (a) $0 \mathrm{Cr}$ and (b) $2 \mathrm{Cr}$ alloy tested at $A_{\mathrm{f}}+30^{\circ} \mathrm{C}$. 
increase on grain refinement, similar in nature to the results observed on testing in the martensite state (Figure 5), and can be explained on the basis of resistance to twin boundary movements imposed by the smaller grain size. It is also observed from Figures 7 and 8 that the PE shape recovery decreases with decreasing $\boldsymbol{\beta}$-grain size. This result is comparable to the previous ones reported in other Cu-based alloys [9]. Such a reduction in the PE properties attendant on grain refinement may be explained as due to the introduction of much higher density of slip defects which is to be expected from the increased value of $\sigma_{\mathrm{c}}$ and $\delta \sigma_{\mathrm{PE}} / \delta \varepsilon$ with reduction in the grain size.

\section{Conclusions}

1. Additions of more than 0.1 at. $\% \mathrm{~V}$ or 1 at. $\% \mathrm{Cr}$ to the $\mathrm{Cu}-\mathrm{Al}-\mathrm{Mn}$ alloys decrease the parent phase $\beta$ grain size. This reduction in grain size is due to the pinning effect of the dispersed $V$ or Cr particles segregated to the grain boundary.

2. The martensitic transformation temperatures in the $\mathrm{Cu}-\mathrm{Al}-\mathrm{Mn}$ alloys decrease with decreasing $\beta$ grain size. A Hall-Petch type relation exists between the martensitic transformation temperatures and the $\beta$-grain size.

3. Addition of $\mathrm{V}$ is effective in improving the room temperature ductility of $\mathrm{Cu}$-Al-Mn alloys by $\beta$-grain refinement. Additions of $\mathrm{Cr}$ to $\mathrm{Cu}-\mathrm{Al}-\mathrm{Mn}$ also reduce the $\beta$-grain size, but they also decrease the ductility drastically.

4. The yield stress $\sigma_{\mathrm{y}}$ and the work hardening rate $\delta \sigma_{\mathrm{M}} / \delta \varepsilon$ in the martensitic state and the yield stress $\sigma_{\mathrm{c}}$ and the work hardening rate $\delta \sigma_{\mathrm{PE}} / \delta \varepsilon$ in the pseudo-elastic state increase with increasing grain constraint. PE properties decrease with decreasing $\beta$-grain size, because of the introduction of much higher density of slip defects at increased stresses.

\section{Acknowledgements}

The authors wish to thank Mr. S. Takahashi for help with the experimental work. They also wish to thank Dr L. Chandrasekaran of DERA, UK for helping in preparation of this manuscript for presentation. This work was supported by the Grant-in-aids for Scientific Research from the Ministry of Education, Science, Sports and Culture, Japan.

\section{Reference}

[1] T. Tadaki : Shape Memory Materials, edited by Otsuka and Wayman, Cambridge University Press. p97

[2] S. Miyazaki and K. Otsuka : ISIJ Int., 29 (1989) 353.

[3] R. Kainuma, N. Satoh, X.J. Liu, I. Ohnuma and K. Ishida : J. Alloys Compounds, 266 (1998) 191.

[4] R. Kainuma, S. Takahashi and K. Ishida : Metall. Mater. Trans. A, 27A (1996) 2187.

[5] R. Kainuma, S. Takahashi and K. Ishida : J. de Phys. IV (1995) C8-961.

[6] Y. Sutou, R. Kainuma and K. Ishida : Mat. Sci. Eng. A, A273-275 (1999) 375.

[7] G. S. Ansell, P. J. Brofman, T. J. Nichol and G. Judd : Proc. ICOMAT-79, Cambridge, (1979) 350.

[8] P. J. Brofman and G. S. Ansell : Metall. Trans. A, 14A (1983) 1929.

[9] Dvorak and E. B. Hawbolt : Metall. Trans. A, 6A (1975) 95.

[10]Dewa N. Adnyana : Metallography 18 (1985) 187.

[11]Q. Khan and L. Delaey : Scripta Met., 4 (1970) 981.

[12] G.N. Sure and L.C. Brown : Metall. Trans. A, 15A (1984) 1613.

[13] S.M. White, J.M. Cook and W.M. Stobbs : J. de Phys. (1982) C4-779. 